\title{
Effects of substituents on anticancer activity of thiosemicarbazone against MCF-7 human breast cancer cell line
}

\section{Belay Zeleke Sibuha ${ }^{a}$ Pankaj Taneja ${ }^{a}$ and Sonia Khanna ${ }^{b}$}

a Department of Biotechnology, School of Engineering and Technology, Sharda University, Greater Noida (U.P), India. email: belayzeleke63@yahoo.com

a Department of Biotechnology, School of Engineering and Technology, Sharda University, Greater Noida (U.P), India.

email: pankjtnj@gmail.com

b Department of Chemistry and Biochemistry, School of Basic Sciences and Research, Sharda University, Greater Noida (U.P), India. email:sonia khanna2005@yahoo.com

Corresponding author: Pankaj Taneja (Associate Professor), Tel. +918920816316/ +919560813083

email: pankjtnj@gmail.com_or pankaj.taneja@sharda.ac.in

Key words: Cytotoxicity, Thiosemicarbazone, MCF-7 breast cancer cell line, MTT Assay, Substituent.

Running Title: Invitro anticancer activity of Thiosemicarbazones on MCF-7 tumor cell

Type of study: Experimental

Date of submission :10 th of February, 2020 


\section{Abstract:}

Background/Aim: Breast cancer is one of the world's leading cause of deaths in women. This study evaluated the in-vitro anticancer activity of different thiosemicarbazones (HacTSc, HSTsc, 3-MBTSc, 4-NBTSc and 4-HBTSC) against MCF-7 human breast cancer cell line and MCF-10 normal cell.

Materials and Methods: The ligands were prepared and characterized by UV vis, IR, ${ }^{1} \mathrm{H}$ NMR. MTT assay was used to determine cell viability. Then data were analyzed using two-way ANOVA with Tukey post-hoc test. Result: The ligands have $I C_{50}$ value ranging from $2.271 \mu \mathrm{g} / \mathrm{ml}$ to $7.081 \mu \mathrm{g} / \mathrm{ml}$. Acetone thiosemicarbazone and 3Methoxybenzaldehyde thiosemicarbazone, were identified as the most potent against MCF-7 breast cancer cells with $I C_{50}$ value of $2.271 \mu \mathrm{g} / \mathrm{ml}$ and $2.743 \mu \mathrm{g} / \mathrm{m} /$ respectively. Whereas 4-Nitrobenzaldehyde thiosemicarbazone was the least potent. Also, the $I_{50}$ of the normal MCF-10 cell indicated their activity were selective. Conclusion: The activity of the ligands were dose, position and substituents dependent. Acetone thiosemicarbazone and 3-Methoxybenzaldehyde thiosemicarbazone are promising anticancer agents for further study. 


\section{Introduction}

Thiosemicarbazones (hydrazine carbothioamides) are a family of compounds with high biological activity (1). Due to their versatile biological and pharmacological activities, their derivatives are of particular importance. They are good intermediates for pharmaceutical and bio-active material synthesis and are therefore, commonly used in medicinal chemistry field. They have also found their way into all branches of chemistry; they are used commercially as dyes, photographic films, plastic and textiles (2). In the past years, thiosemicarbazone derivatives have shown a wide range of biological activity viz. antifungal $(3,4)$, anti-tumor/cancer (5-10), Antimicrobial (11-13), sodium channel blocker (14), antiviral $(15,16)$.

Cancer is a malignant and invasive growth or tumor, especially of epithelium origin, which tends to recur after excision and may metastasize to other sites. It occurs due to failure of the mechanism that usually controls the growth and proliferation of cells (17). Cancer may affect people of all ages, and with increase in age the exposure to most type of cancer increases. Similarly, it can affect all parts of the body, for instance, lung and breast cancers are common all over the world (18).

Breast cancer is the most common type of cancer and the second leading cause of death among women worldwide (19). It affects 2.1 million women each year, and in 2018, an estimated 627,000 women died from breast cancer - about $15 \%$ of all female cancer deaths. While the rates of breast cancer among women are higher in developed region, rates are increasing globally in almost in every country (20). 
Studies have shown that multi-drug resistance and unwanted side effects of current cancer chemotherapeutic contribute to an increased interest towards the development of new anticancer cancer drug, including synthetic compounds with minimal toxicity to normal tissue and highly effective with lower tumor cell resistance $(21,22)$. The present work is designed to evaluate the cytotoxic effects of different thiosemicarbazones on MCF-7 human breast cancer cell line.

\section{Material and Methods}

All chemicals used were commercial products of analytical reagent grade procured from Sigma-Aldrich, except for the ligands, which were prepared by the reaction of $\mathrm{MeOH}$ and water solutions with different substituent and thiosemicarbazide using the procedures depicted below.

Synthesis of Acetone Thiosemicarbazone (HacTsc): Acetone thiosemicarbazone $\left(\mathrm{C}_{4} \mathrm{H}_{9} \mathrm{~N}_{3} \mathrm{~S}\right)$ was prepared by refluxing and stirring a mixture of acetone $(0.02 \mathrm{mmol}, 1.16 \mathrm{~g})$ and thiosemicarbazide $(0.02 \mathrm{mmol}, 1.822 \mathrm{~g})$ in $20 \mathrm{ml}$ distilled water. The mixture was refluxed for $15 \min \left(40^{\circ} \mathrm{C}\right)$ and stirred for while resulting yellow colored solution, which was kept undisturbed. Then, a crystalline white product was separated out. Yield, $2.68 \mathrm{~g}$, Insoluble in: $\mathrm{CHCl}_{3}, \mathrm{CCl}_{4}, \mathrm{H}_{2} \mathrm{O}$; soluble in $\mathrm{DMSO}, \mathrm{DHF} / \mathrm{THF}, \mathrm{CH}_{3} \mathrm{CN}$, ethanol, Methanol<smiles>CC(C)=O</smiles>

Acetone<smiles>NNC(N)=S</smiles>

Thiosemicarbazide

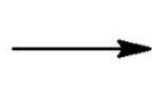

Figure 1 Preparation of Acetone thiosemicarbazone<smiles>CC(C)=NNC(N)=S</smiles>

Acetone thiosemicarbazone 
Synthesis of Salicylaldehyde Thiosemicarbazone (HSTSc): Salicylaldehyde thiosemicarbazone, $\mathrm{C}_{8} \mathrm{H}_{9} \mathrm{~N}_{3} \mathrm{OS}$, was prepared by refluxing the mixture of salicylaldehyde $(2.4 \mathrm{ml}, 0.01 \mathrm{mmol})$ and thiosemicarbazide $(2.0 \mathrm{~g}, 0.01 \mathrm{mmol})$ in a mixture of methanol (30 $\mathrm{ml})$ and distilled water $(30 \mathrm{ml})$ as the solvent medium in the presence of glacial acetic acid (2-3 ml). The reaction mixture was refluxed for about 3-4 hours, resulting in a yellow colored solution, which was kept undisturbed. The next day, a crystalline yellow product was separated out. Yield, $4.046 \mathrm{~g}$, melting point $259^{\circ} \mathrm{C}$. Insoluble in: $\mathrm{CHCl}_{3}, \mathrm{CCl}_{4}, \mathrm{CH}_{3} \mathrm{CN}$, $\mathrm{H}_{2} \mathrm{O}$; soluble in DMSO, DHF/THF

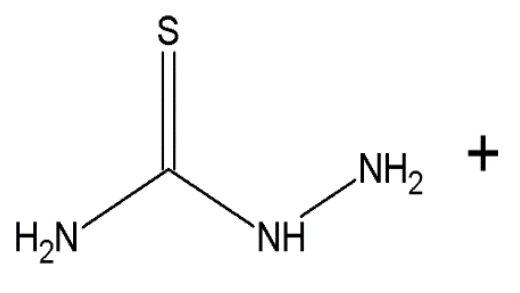

thiosemicarbazide<smiles>CCCCC=O</smiles>

Salicylaldehyde<smiles>NC(=S)N/N=C/c1ccccc1O</smiles>

Salicylaldehyde thiosemicarbazone

Figure 2 Preparation of salicylaldehyde thiosemicarbazone

Synthesis of 3-Methoxy benzaldehyde thiosemicarbazone (3-MBTsc): 3- Methoxy benzaldehyde thiosemicarbazone, $\mathrm{C}_{9} \mathrm{H}_{11} \mathrm{~N}_{3} \mathrm{OS}$, was prepared by refluxing a mixture of 3Methoxy benzaldehyde $(1.22 \mathrm{ml}, 0.01 \mathrm{mmol})$ and thiosemicarbazide $(0.91 \mathrm{~g}, 0.01 \mathrm{mmol})$ in a mixture of methanol $(20 \mathrm{ml})$ and distilled water $(20 \mathrm{ml})$ as the solvent medium in the presence of glacial acetic acid $(2-3 \mathrm{ml})$. The reaction mixture was refluxed for about 3-4 hours. Next day yellow crystalline compound separated out. Yield, 2.16g; Insoluble in: $\mathrm{CHCl}_{3}, \mathrm{CCl}_{4}, \mathrm{CH}_{3} \mathrm{CN}, \mathrm{H}_{2} \mathrm{O}$; ethanol, methanol; soluble in DMSO, DHF/THF 


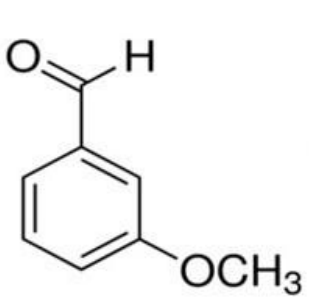

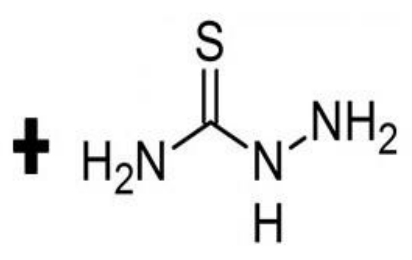

Thiosemicarbazide
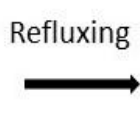

3-Methoxy benzaldehyde

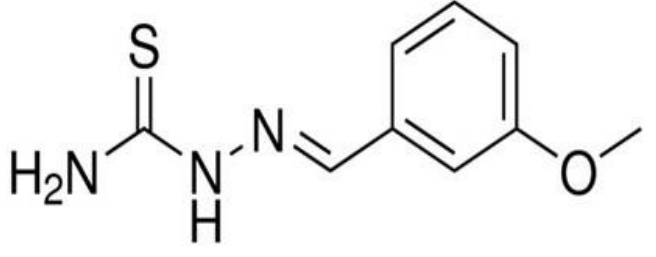

3- Methoxy benzaldehyde Thiosemicarbazone

Figure 3 Synthesis of 3-Methoxy benzaldehyde thiosemicarbazone (3-MBTSc)

Synthesis of 4-Nitrobenzaldehyde thiosemicarbazone (4-NBTSc): 4- Nitro benzaldehyde thiosemicarbazone was prepared by simple stirring 4-Nitrobenzaldehyde $(1.51 \mathrm{~g}, 0.01 \mathrm{mmol})$ and thiosemicarbazide $(0.914 \mathrm{~g}, 0.01 \mathrm{mmol})$ in a mixture of methanol $(15 \mathrm{ml})$ and distilled water $(15 \mathrm{ml})$ as a solvent medium. The reaction mixture was stirred for about 2 hours, resulting a yellow crystalline compound, which was kept undisturbed. Then a yellow crystalline compound was separate out. Yield, $2.30 \mathrm{~g}$; Insoluble in: $\mathrm{CHCl}_{3}$, $\mathrm{CCl}_{4}, \mathrm{CH}_{3} \mathrm{CN}, \mathrm{H}_{2} \mathrm{O}$, ethanol, Methanol; soluble in DMSO and DHF/THF<smiles>NNC(N)=S</smiles>

Thiosemicarbazide

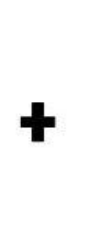

4- Nitro benzaldehyde

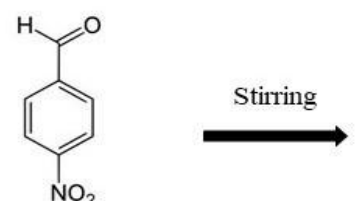

$\mathrm{H}_{2} \mathrm{~N}^{-}$<smiles>NC(=S)N/N=C/c1ccc([N+](=O)[O-])cc1</smiles>

4- Nitro benzaldehyde Thiosemicarbazone

Figure 4 Synthesis of 4-Nitro benzaldehyde thiosemicarbazone

Synthesis of 4-Hydroxybenzaldehyde thiosemicarbazone (4-HBTSc): 4-hydroxy benzaldehyde (4-HBTSc) was prepared by refluxing a mixture of 4-hydroxybenzaldehyde $(1.222 \mathrm{~g}, 0.01 \mathrm{mmol})$ and thiosemicarbazide $(0.914 \mathrm{~g}, 0.01 \mathrm{mmol})$ in a mixture of methanol $(15 \mathrm{ml})$ and distilled water $(10 \mathrm{ml})$ as a solvent medium. The reaction mixture was refluxed 
for about 5 hours, resulting a light-yellow colored solution, which was kept undisturbed. Then a light-yellow crystalline compound was separate out. Yield: $1.708 \mathrm{~g}$, melting point: $207^{\circ} \mathrm{C}$; insoluble in $\mathrm{CHCl}_{3}, \mathrm{CCl}_{4}, \mathrm{H}_{2} \mathrm{O}$, ethanol; soluble in DMSO, DHF/THF, $\mathrm{CH}_{3} \mathrm{CN}$, Methanol<smiles>NNC(N)=S</smiles>

thiosemicarbazide<smiles>CCCCCC=O</smiles>

4-hydroxybenzaldehyde<smiles>NC(=S)N/N=C/c1ccc(O)cc1</smiles>

4-hydroxybenzaldehyde thiosemicarbazone

Figure 5 Preparation of 4-hydroxybenzaladehyde thiosemicarbazone

Physical measurements: The structure of the ligand was confirmed from UV-Vis, infrared and ${ }^{1} \mathrm{H}$ NMR spectral studies. UV Vis Spectroscopy was done by taking DMSO as reference sample or blank. The infrared spectroscopy was conducted to check whether the ligand is properly prepared or not. Also, ${ }^{1} \mathrm{H}$, nuclear magnetic resonance (NMR) spectra was measured in dimethyl sulfoxide (DMSO)-d6 as internal reference at ambient temperature. Also, the physical properties of the compounds were checked.

Cell lines and cell culture: The test compound was studied for short-term in vitro anticancer activity against MCF-7 breast cancer cell line and for comparison, MCF-10 normal cell line was used. The cell lines were initially procured from the National Centre for Cell Science, Pune (NCCS). Cells were cultured in a 6 walled culture plate using Dulbecco's Modified Eagle's Medium, that was supplemented with $10 \%$ fetal bovine serum at $95 \%$ air condition with $5 \%$ of carbon dioxide $\left(\mathrm{CO}_{2}\right)$ in $37^{\circ} \mathrm{C}$ Temperature. 
MTT cell viability assay Cell count: Before the cell viability test conducted cells were counted using hemocytometer $\left(\times 10^{4} \mathrm{cell} / \mathrm{ml}\right)$. Then cell viability was assessed by MTT assay using ATCC MTT Cell Proliferation Assay kit. MCF-7 and MCF-10 cell lines were plated separately in 96 well plates at a concentration of $1 \times 10^{4}$ cells $/$ well. After $48 \mathrm{hr}$. the media was removed and cells were washed twice with $100 \mu \mathrm{l}$ serum-free medium. Then $10 \mu \mathrm{l}$ MTT Reagent was added and left for incubation for $4 \mathrm{~h}$ at $37^{\circ} \mathrm{C}$ in a $\mathrm{CO} 2$ incubator, until intracellular purple formazan crystals are visible (until purple precipitate is visible). After that, MTT containing medium was discarded, the cells were washed with PBS $(200 \mu \mathrm{l})$. The crystals were then dissolved by adding $100 \mu \mathrm{l}$ of DMSO and mixed properly by pipetting up and down and left at room temperature in the dark for 2 hours. Spectro photometrical absorbance of the purple blue formazan dye was measured in a microplate reader at $570 \mathrm{~nm}$. Then, percent Cell viability was calculated using the following formula.

$\%$ Cell viability $=\frac{\text { Mean absorbance of treated }}{\text { Mean absorbance of untreated }} \times 100$

Evaluation of anticancer potential: The in vitro anticancer activities of the test ligands were studied for short-period of time. First, $1 \mathrm{mg}$ of the synthesized thiosemicarbazone ligand was dissolved in $1 \mathrm{ml}$ of Dimethyl sulfoxide (DMSO) separately. The test was done by taking the desired doses directly (without further dilution). Hence, the study was conducted in five concentrations including the control group (i.e. $0,5 \mu \mathrm{g} / \mathrm{ml}, 10 \mu \mathrm{g} / \mathrm{ml}, 12$ $\mu \mathrm{g} / \mathrm{ml}, 20 \mu \mathrm{g} / \mathrm{ml}$ of the test ligand) for each of the cell lines used. Based on the prepared test drug concentrations we have assigned the following groups. Group I: the cell line was subjected only for $10 \mu \mathrm{l}$ DMSO (control); Group II: $5 \mu \mathrm{g} / \mathrm{ml}$ of the test ligand; Group III, $10 \mu \mathrm{g} / \mathrm{ml}$ of the test ligand; Group IV, $12 \mu \mathrm{g} / \mathrm{ml}$ test ligand; Group V, $20 \mu \mathrm{g} / \mathrm{ml}$ test ligand. 
Statistical analysis: Data is presented in the form of descriptive statistics through tables and graphs. Descriptive Statistical analysis was done using Microsoft Excel. Whereas, $\mathrm{IC}_{50}$ value was calculated by fitting the sigmoidal dose response model (curve) by means of Prism statistical software package. Also, a two-way ANOVA and mean comparison test using Tukey multiple comparison test were analyzed in Prism statistical software package (GraphPad Software, Inc., La Jolla, CA, USA). $P<0.05^{*}$ was considered statistically significant.

\section{Results}

The synthesis of different thiosemicarbazones were carried out according to the steps depicted in materials and methods section. The structures of the ligands were confirmed from UV-Vis, infrared and ${ }^{1} \mathrm{H}$ NMR spectral studies.

\section{Anticancer activity of different thiosemicarbazone on MCF-7 breast cancer cell:}

MTT assay was used to test the anticancer activity of different substituent of thiosemicarbazone on MCF-7 breast cancer and MCF-10 normal cells. The half inhibitory concentration $\left(\mathrm{IC}_{50}\right)$ of the test compounds was calculated using GraphPad prism software and presented in table1. According to the $\mathrm{IC}_{50}$ value, Acetone thiosemicarbazone by having $\mathrm{IC}_{50}$ value of $2.271 \mu \mathrm{g} / \mathrm{ml}$ is found to be the most potent and 4- Nitro benzaldehyde with $\mathrm{IC}_{50}$ value of $7.081 \mu \mathrm{g} / \mathrm{ml}$ is found to be the least potent. On the other hand, 3-methoxybenzaldehyde TSc $\left(\mathrm{IC}_{50}=2.743 \mu \mathrm{g} / \mathrm{ml}\right)$ showed a comparable activity with Acetone thiosemicarbazone. On the other hand, the $\mathrm{IC}_{50}$ values of those ligands used in MCF-10 were higher than that of MCF-7 except in 4-nitro benzaldehyde where it is lower $(2.255 \mu \mathrm{g} / \mathrm{ml})$. 
Acetone thiosemicarbazone inhibit the growth MCF-7 breast cancer cell line in lower concentration: The growth inhibition effect of HacTSc on MCF-7 and MCF-10 cells treated with different concentration was tested using MTT assay. The result (table 2 and figure $6 \mathrm{~A}$ ) suggested that, HaTSc inhibit approximately $6 \%$ percent of the tumor cell at concentration of $5 \mu \mathrm{g} / \mathrm{ml}$ and decrease to $3.5 \%$ cell as the concentration increased to $20 \mu \mathrm{g} / \mathrm{ml}$. The ligand's toxicity to the normal cell showed cell viability increased as the concentration increase. This result suggests that Acetone thiosemicarbazone might be effective if it is used in very minimal concentration than high concentration.

\section{Salicylaldehyde thiosemicarbazone inhibit the growth MCF-7 breast cancer cell} line: The MTT assay result showed that HSTSc has highly significant $(p<0.001)$ growth inhibition on MFC-7 and MCF-10 cell. As depicted in table 3 and figure 6B, the test ligand showed $19 \%$ to $25 \%$ growth inhibition of MCF-7 when the concentration increased from $5 \mu \mathrm{g} / \mathrm{ml}$ to $20 \mu \mathrm{g} / \mathrm{ml}$. On the other hand, MCF-10 growth inhibition suggest that the compound is less toxic to the normal cell with $97.6 \%$ and $96.8 \%$ of viable cell after treatment of $5 \mu \mathrm{g} / \mathrm{ml}$ and $20 \mu \mathrm{g} / \mathrm{ml}$ respectively.

Effect of 3-Methoxy benzaldehyde thiosemicarbazone on cell viability: As presented in table 4 and figure 6C, 3-MBTSc showed a very promising and a significant $(p<0.001)$ growth inhibition activity. It inhibits almost $33 \%$ of tumor cell growth at $5 \mu \mathrm{g} / \mathrm{ml}$ and continue up to $36.5 \%$ at $20 \mu \mathrm{g} / \mathrm{ml}$. Comparing its toxicity to the normal cell at the same concentration the ligand inhibits $7-8 \%$ of MCF-10 cell growth.

The effect of 4- Nitro benzaldehyde thiosemicarbazone on cell viability: As demonstrated in table 5 and figure 6D, 4-NBTSc inhibits around $13 \%$ of cells growth and continue up to $40 \%$ with increase in concentration from $5 \mu \mathrm{g} / \mathrm{ml}$ to $20 \mu \mathrm{g} / \mathrm{ml}$. Also, the test 
ligand showed constant inhibition increment with small change in treatment concentration; at $10 \mu \mathrm{g} / \mathrm{ml}$ its effect was $25 \%$ and it increase by $9 \%$ and inhibit $34 \%$ of the cells while the dose is only $12 \mu \mathrm{g} / \mathrm{ml}$. However, the ligand showed slight toxicity to normal cells and it inhibit $12-16 \%$ MCF-10 cell growth. This output suggested that the activity of this ligand is promising but it might not be selective.

\section{The effect of 4- hydroxy benzaldehyde thiosemicarbazone on cell viability:} According to the MTT assay result (table 6 and figure 6E), 4- HBTSc showed a very promising and highly significant $(\mathrm{p}<0.001)$ growth inhibition effect on MFC-7 and MCF-10 cells. It showed a $49.27 \%$ growth inhibition at dose of $20 \mu \mathrm{g} / \mathrm{ml}$. Surprisingly at the concentration of $5 \mu \mathrm{g} / \mathrm{ml}$ it inhibits $38 \%$ of MCF-7 cells growth while it only inhibits $3 \%$ of MCF-10 normal cell. This result indicted that the compound is very promising for further study.

\section{Discussion}

It was reported that structural variation, type substituent, cancer types and dose can affect the function of the compound (23-26). The $\mathrm{IC}_{50}$ and the ANOVA result in the current study also confirmed that, the activities of the ligands were significantly varied due to substituent type, dose and the type of cell line. As indicated in table 1, Acetone thiosemicarbazone with the $\mathrm{IC}_{50}$ value of $2.271 \mu \mathrm{g} / \mathrm{ml}$ is found to be the most potent and 4- Nitro benzaldehyde with $\mathrm{IC}_{50}$ value of $7.081 \mu \mathrm{g} / \mathrm{ml}$ is found to be the least potent. Acetone, which is the simplest and the smallest Ketone as a substituent showed a better anticancer activity than all aldehyde substituents used for this study. This could be correlated with the location of the substituent, as acetone is positioned with non-aromatic nature, while 
the other ligand substituents are located in the different position of the benzene ring. Conversely, among the benzene ring substituents we synthesized the methoxy group in 3-methoxy benzaldehyde thiosemicarbazone showed a better activity than the Nitro and hydroxy substituent. In fact, when we see the activity of the hydroxy group on its own, the effect of the substituent position is found to be lower.

Similarly, MCF-10 normal cell line was used to determine whether the test compounds were toxic or nontoxic to healthy cells. The $\mathrm{IC}_{50}$ values of those ligands used in MCF-10 were higher than that of MCF-7 except in 4-nitro benzaldehyde where it is lower. These results generally indicated that most of the ligands are selective in their anticancer effect. Particularly Acetone thiosemicarbazone showed highly selective activity with an $\mathrm{IC}_{50}$ value of $115.8 \mu \mathrm{g} / \mathrm{ml}$ against the normal cell line. On the contrary, 4- nitro benzaldehyde showed highly toxic activity with $\mathrm{IC}_{50}$ value of $2.255 \mu \mathrm{g} / \mathrm{ml}$ to the normal cell line.

The cell viability result revealed that the inhibition of cell growth significantly increased with an increase in dose and varies with a substituent except for Acetone thiosemicarbazone where the inhibition has decreased as the dose increases (Table 2 to 6). In MCF-7 breast cancer cell line, the highest percentage of inhibition (i.e. $49.27 \%$, 48.19 and $47.83 \%$ ) was observed on cells treated with 4 -HBTSc at the dose of 20,12 and $10 \mu \mathrm{g} / \mathrm{ml}$ respectively. The other ligands also showed a mild and comparable effect. In line with this, with an increase in dose, 4-NBTSc and 3-MBTSc showed 40\% and 35 $\%$ of growth inhibition respectively (table 4 and 5). On the contrary, the lowest growth inhibition effect was observed at doses of $20 \mu \mathrm{g} / \mathrm{ml}$ (table 2) due to HacTSc. Theoretically, 
the lowest $\mathrm{IC}_{50}$ is associated with the highest anticancer activity, and the highest cell growth inhibition. Thus, in the current study most of the percentage of cell death due to inhibition of cell growth is consistent with the $\mathrm{IC}_{50}$ value of the test ligands. Nevertheless, when we see the effect of Acetone thiosemicarbazone, its inhibition of growth decreased as the dose increased (5.4\% to $3.6 \%)$. This could mean that HacTSc could be effective if it is used at small concentration. Generally, all test ligands showed significant $\left(p<0.05^{\star}\right.$, $\left.\mathrm{P}<0.001^{* * *}\right)$ growth inhibition between MCF-7 and MCF-10 cells except 4-NBTSc which showed statistically non-significant effect on cell viability between tumor and normal cells. This could be due to the toxic nature of 4-NBTSc to the normal cell (MCF-10) which inhibits growth in close range with MCF-7 breast cancer cell. In conclusion, the test ligands showed potential as anti-tumor agents for further in-vitro and/or in-vivo stages of screening, encouraging further research in this field.

\section{Conflicts of Interest}

The Authors have no conflicts of interest to declare regarding this study.

\section{Authors' Contributions}

All authors contribute equally in Research concept and design, data collection, Data analysis and interpretation, writing; critical revision and Final approval of the article.

\section{Acknowledgement}

The authors would like to acknowledge Sharda university for their material support. Also, Belay Zeleke would like to thank Arba Minch University, Ethiopia, for sponsoring his Ph.D. study.

\section{Funding Sources}

This research was funded by Sharda University, as part of PhD thesis research work. 


\section{References}

1 Alomar K, Khan MA, Allain M and Bouet G: Synthesis, crystal structure and characterization of 3-thiophene aldehyde thiosemicarbazone and its complexes with cobalt(II), nickel(II) and copper(II). Polyhedron 28: 1273-1280, 2009.

2 Tada R, Chavda N and Shah MK: Synthesis and characterization of some new thiosemicarbazide derivatives and their transition metal complexes. J Chem Pharm Res 3: 290-297, 2011.

3 Devi J, Yadav M, Jindal DK, Kumar D and Poornachandra Y: Synthesis, spectroscopic characterization, biological screening and in vitro cytotoxic studies of 4-methyl-3-thiosemicarbazone derived Schiff bases and their Co (II), Ni (II), Cu (II) and Zn (II) complexes. Appl Organomet Chem 33: 1-23, 2019.

4 Gałczyńska K, Ciepluch K, Madej $Ł$, Kurdziel K, Maciejewska B, Drulis-Kawa Z, Węgierek-Ciuk A, Lankoff A and Arabski M: Selective cytotoxicity and antifungal properties of copper(II) and cobalt(II) complexes with imidazole-4-acetate anion or 1-allylimidazole. Sci Rep 9: 1-13, 2019.

5 Yu P, Deng J, Cai J, Zhang Z, Zhang J, Hamid Khan M, Liang H and Yang F: Anticancer and biological properties of a Zn-2,6-diacetylpyridine bis(thiosemicarbazone) complex. Metallomics 11: 1372-1386, 2019.

6 Bisceglie F, Orsoni N, Pioli M, Bonati B, Tarasconi P, Rivetti C, Amidani D, Montalbano S, Buschini A and Pelosi G: Cytotoxic activity of copper(ii), nickel(ii) and platinum(ii) thiosemicarbazone derivatives: Interaction with DNA and the H2A histone peptide. Metallomics 11: 1729-1742, 2019.

7 Palamarciuc O, Milunović MNM, Sîrbu A, Stratulat E, Pui A, Gligorijevic N, Radulovic S, Kožíšek J, Darvasiová D, Rapta P, Enyedy EA, Novitchi G, Shova S and Arion VB: Investigation of the cytotoxic potential of methyl imidazole-derived thiosemicarbazones and their copper(ii) complexes with dichloroacetate as a coligand. New J Chem 43: 1340-1357, 2019.

8 Kaur H, Gupta VK and Gupta M: Synthesis and Anti Proliferative Activity of Thiosemicarbazone and 4-Thiazolidinones. 2-10, 2019.

9 Muralisankar M, Dheepika R, Haribabu J, Balachandran C, Aoki S, Bhuvanesh NSP and Nagarajan S: Design, Synthesis, DNA/HSA Binding, and Cytotoxic Activity of Half-Sandwich $\mathrm{Ru}(\mathrm{II})$-Arene Complexes Containing TriarylamineThiosemicarbazone Hybrids. ACS Omega 4: 11712-11723, 2019.

10 Aguirre AR, Parrilha GL, Diniz R, Ribeiro BC, Santos RGD and Beraldo H: Cytotoxic effects of indium(III) complexes with 2-acetylpyridine-N(4)-orthofluorophenylthiosemicarbazone and their radioactive $114 \mathrm{mln}$ analogues against human glioma cells. Polyhedron 164: 219-227, 2019.

11 Polo-Cerón $\mathrm{D}: \mathrm{Cu}(\mathrm{II})$ and $\mathrm{Ni}(\mathrm{II})$ complexes with new tridentate NNS thiosemicarbazones: Synthesis, characterisation, DNA interaction, and 
antibacterial activity. Bioinorg Chem Appl 2019, 2019.

12 Bhattacharya M, Iqbal SA and Malik S: Spectral and diuretic study of $\mathrm{Cu}$ (II) complex of Sulfonamides. Der Chem Sin 3: 1204-1212, 2012.

13 Kalapala V, Banothu V, K. B. Chandra S and Mukkantia K: Synthesis and characterization of some new thiosemicarbazide derivatives and their transition metal complexes. J Chem Pharm Res 7: 437-445, 2015.

14 Dakshayani K, Lingappa Y, Sayaji Rao M NLDM and DK: Synthesis, Characterization and Biological Activity of 5 - Methyl, Thiophene -2Carboxaldehyde Derivatives of Copper (II), Cobalt (II) and Nickel (II) Complexes. Res Pap Int J Chem Pharm Sci 3: 50-55, 2012.

15 Belicchi Ferrari M, Bisceglie F, Pelosi G, Sassi M, Tarasconi P, Cornia M, Capacchi S, Albertini R and Pinelli S: Synthesis, characterization and X-ray structures of new antiproliferative and proapoptotic natural aldehyde thiosemicarbazones and their nickel(II) and copper(II) complexes. J Inorg Biochem 90: 113-126, 2002.

16 Chandra JS, Kumari YASJP, Rani PNVVLP and Sunandamma Y: Anthraquinone benzylthiosemicarbazone $\mathrm{Cr}$ (III) complex as a potential anti-cancer drug characterization and activity. Indian J Adv Chem Sci 2: 32-37, 2013.

17 Greaves M and Maley CC: Clonal evolution in cancer. Nature 481: 306-313, 2012.

18 Anand P, Kunnumakara AB, Sundaram C, Harikumar KB, Tharakan ST, Lai OS, Sung $B$ and Aggarwal BB: Cancer is a preventable disease that requires major lifestyle changes. Pharm Res 25: 2097-2116, 2008.

19 Iorns E, Drews-Elger K, Ward TM, Dean S, Clarke J, Berry D, Ashry D El and Lippman M: A New Mouse Model for the Study of Human Breast Cancer Metastasis. PLoS One 7, 2012.

20 Organization WH: WHO | Breast cancer. WHO, 2018. Available from: https://www.who.int/cancer/prevention/diagnosis-screening/breast-cancer/en/ [last accessed January 23, 2020].

21 Hajrezaie M, Paydar M, Looi CY, Maghadamtousi SZ, Hassandarvish P, Salga MS, Karimian H, Shams K, Zahedifard M, Majid NA, Ali HM and Abdulla MA: Apoptotic effect of novel Schiff Based. Sci Rep 5: 1-11, 2015.

22 Marsh S and McLeod HL: Pharmacogenetics and oncology treatment for breast cancer. Expert Opin Pharmacother 8: 119-127, 2007.

23 Lobana TS, Khanna S, Hundal G, Kaur P, Thakur B, Attri S and Butcher RJ: Coinage metal derivatives of salicylaldehyde thiosemicarbazones: Synthesis, structures, bond isomerism and H-bonded networks. Polyhedron 28: 1583-1593, 2009.

24 Bal-Demirci T, Congur G, Erdem A, Erdem-Kuruca S, Özdemir N, Akgün-Dar K, Varol B and Ülküseven B: Iron(III) and nickel(ii) complexes as potential anticancer agents: Synthesis, physicochemical and structural properties, cytotoxic activity and 
DNA interactions. New J Chem 39: 5643-5653, 2015.

25 Afrasiabi Z, Sinn E, Chen J, Ma Y, Rheingold AL, Zakharov LN, Rath N and Padhye S: Appended 1,2-naphthoquinones as anticancer agents 1: Synthesis, structural, spectral and antitumor activities of ortho-naphthaquinone thiosemicarbazone and its transition metal complexes. Inorganica Chim Acta 357: 271-278, 2004.

26 Atasever B, Ülküseven B, Bal-Demirci T, Erdem-Kuruca $S$ and Solakoğlu Z: Cytotoxic activities of new iron(III) and nickel(II) chelates of some S-methylthiosemicarbazones on K562 and ECV304 cells. Invest New Drugs 28: 421-432, 2010.
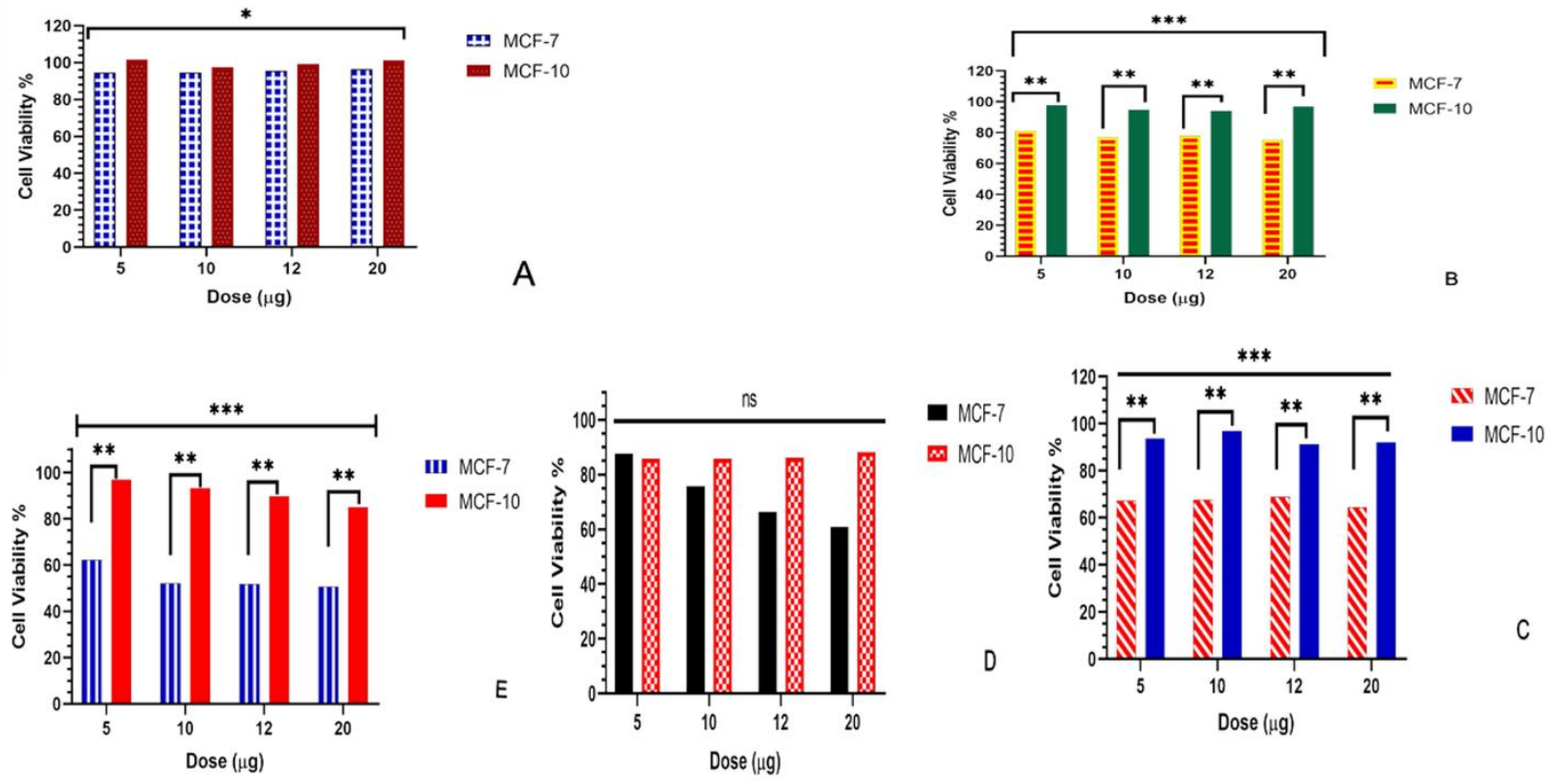

Figure 6. Effect of different thiosemicarbazone on cell viability (A) Acetone TSc (B) Salicylaldehyde TSc (C) 3-Methoxybenzaldehyde TSc (D) 4-Nitrobenzaldehyde TSC (E) 4Hydroxybenzaldehyde TSC 
Table 1. IC 50 values of the ligands against MCF-7 and MCF-10 cell lines

\begin{tabular}{|l|l|l|}
\hline \multirow{2}{*}{ Cell line } & \multicolumn{2}{|c|}{ IC 50 $\mathrm{g} / \mathrm{ml}$ value } \\
\cline { 2 - 3 } & MCF-7 & MCF-10 \\
\hline Acetone TSc (HacTSc) & 2.271 & 115.8 \\
Salicylaldehyde TSc (HSTsc) & 3.361 & 5.399 \\
3-methoxybenzaldehyde TSc (3-MBTSc) & 2.743 & 4.507 \\
4-Nitrobenzaldehyde TSc (4-NBTSc) & 7.081 & 2.255 \\
4-Hydroxybenzaldehyde TSc (4-HBTSc) & 3.605 & 9.55 \\
\hline
\end{tabular}

Table 2 The effect of acetone thiosemicarbazone on cell viability

\begin{tabular}{lllll|l|}
\hline Cell line & Treatment & Mean & Standard & Cell viability & P value \\
& & absorbance & deviation & $(\%)$ & (between cell lines) \\
\hline MCF-7 & 0 (control) & 1.38 & 0.0141 & 100 & \\
& 5 & 1.305 & 0.0212 & 94.565 & \\
& 10 & 1.305 & 0.0212 & 94.565 & \\
& 12 & 1.32 & 0.0141 & 95.652 & \\
& 20 & 1.33 & 0.0141 & 96.377 & \\
\hline MCF-10 & 0 (control) & 1.26 & 0.0141 & 100 & \\
& 5 & 1.28 & 0.0141 & 101.587 & \\
& 10 & 1.23 & 0.0141 & 97.619 & \\
& 12 & 1.25 & 0.0283 & 99.206 & \\
\hline & 1.275 & 0.0212 & 101.190 & \\
\hline
\end{tabular}


Table 3 The effect of Salicylaldehyde thiosemicarbazone on cell viability

\begin{tabular}{lllll|l|}
\hline Cell line & Treatment & $\begin{array}{l}\text { Mean } \\
\text { absorbance }\end{array}$ & $\begin{array}{l}\text { Standard } \\
\text { deviation }\end{array}$ & $\begin{array}{l}\text { Cell viability } \\
(\%)\end{array}$ & $\begin{array}{l}\text { P value } \\
\text { (between cell lines) }\end{array}$ \\
\hline MCF-7 & 0 (control) & 1.38 & 0.0141 & 100 & \\
& 5 & 1.12 & 0.0141 & 81.159 & \\
& 10 & 1.06 & 0.0141 & 76.812 & \\
& 12 & 1.075 & 0.0212 & 77.899 & \\
& 20 & 1.04 & 0.0141 & 75.362 & \\
\hline MCF-10 & 0 (control) & 1.26 & 0.0141 & 100 & \\
& 5 & 1.23 & 0.0141 & 97.619 & \\
& 10 & 1.195 & 0.0071 & 94.841 & \\
& 12 & 1.185 & 0.0071 & 94.048 & \\
\hline & 1.22 & 0.0283 & 96.825 & \\
\hline
\end{tabular}


Table 4 The effect of 3-Methoxy benzaldehyde thiosemicarbazone on cell viability

\begin{tabular}{lllll|l|}
\hline Cell line & Treatment & Mean & Standard & \%cell & P value \\
& & absorbance & deviation & viability & (between cell lines) \\
\hline MCF-7 & 0 (control) & 1.38 & 0.0141 & 100 & \\
& 5 & 0.93 & 0.0141 & 67.391 & \\
& 10 & 0.935 & 0.0071 & 67.754 & \\
& 12 & 0.95 & 0.0141 & 68.841 & \\
& 20 & 0.89 & 0.0141 & 64.493 & \\
\hline MCF-10 & 0 (control) & 1.26 & 0.0141 & 100 & \\
& 5 & 1.18 & 0.0141 & 93.651 & \\
& 10 & 1.22 & 0.0141 & 96.825 & \\
& 12 & 1.15 & 0.0283 & 91.270 & \\
\hline & 1.16 & 0.0141 & 92.063 & \\
\hline
\end{tabular}


Table 5 The effect of 4 - Nitro benzaldehyde thiosemicarbazone on cell viability

\begin{tabular}{lllll|l|}
\hline Cell line & Treatment & Mean & Standard & \%cell & P-value \\
& & absorbance & deviation & viability & (between cell lines) \\
\hline MCF-7 & 0 (control) & 1.38 & 0.0141 & 100 & \\
& 5 & 1.21 & 0.0141 & 87.681 & \\
& 10 & 1.045 & 0.0071 & 75.725 & \\
& 12 & 0.915 & 0.0212 & 66.304 & \\
& 20 & 0.84 & 0.0141 & 60.870 & \\
\hline MCF-10 & 0 (control) & 1.26 & 0.0141 & 100 & \\
& 5 & 1.08 & 0.0141 & 85.714 & \\
& 10 & 1.08 & 0.0141 & 85.714 & \\
& 12 & 1.085 & 0.0071 & 86.111 & \\
& 10 & 1.11 & 0.0141 & 88.095 & \\
\hline
\end{tabular}


Table 6 The effect of 4- hydroxy benzaldehyde thiosemicarbazone on cell viability

\begin{tabular}{lllll|l|}
\hline Cell line & Treatment & Mean & $\begin{array}{l}\text { Standard } \\
\text { absorbance }\end{array}$ & $\begin{array}{l}\text { deviation } \\
\text { viability }\end{array}$ & (between cell lines) \\
\hline MCF-7 & 0 (control) & 1.38 & 0.0141 & 100 & \\
& 5 & 0.86 & 0.0141 & 62.319 & \\
& 10 & 0.72 & 0.0000 & 52.174 & \\
& 12 & 0.715 & 0.0212 & 51.812 & \\
& 20 & 0.7 & 0.0141 & 50.725 & \\
\hline MCF-10 & 0 (control) & 1.26 & 0.0141 & 100 & \\
& 5 & 1.22 & 0.0141 & 96.825 & \\
10 & 1.175 & 0.0212 & 93.254 & \\
12 & 1.13 & 0.0141 & 89.683 & \\
& 10 & 1.07 & 0.0141 & 84.921 & \\
\hline
\end{tabular}

